\title{
SOSIALISASI PENTINGNYA IMUNISASI UNTUK MENCAPAI UNIVERSAL CHILD IMMUZATION (UCI) DI KELURAHAN MAHARANI KECAMATAN RUMBAI
}

\author{
Octa Dwienda R,SKM, M.Kes ${ }^{(1)}$, Nelly Karlinah, SST, M.Keb ${ }^{2)}$ \\ ${ }^{(1),(2)}$ STIKes Hang Tuah Pekanbaru \\ Email: octadwienda@htp.ac.id
}

\begin{abstract}
ABSTRAK
The immunization program is an effort to provide protection to the population against certain diseases. The immunization program is given to populations considered vulnerable to contracting infectious diseases, namely infants, toddlers, children, women of childbearing age, and pregnant women. Through this program, Indonesia has been declared free from smallpox by WHO since 1974. In Indonesia, the immunization program requires every baby (aged 0-11 months) to receive complete basic immunization consisting of 1 dose of Hepatitis $B, 1$ dose of BCG, 3 doses of DPT. -HB-Hib, 4 doses of polio, and 1 dose of measles. One indicator of the success of the immunization program is the achievement of Universal Child Immunization (UCI), which is a state of achieving complete basic immunization for all infants (children under one year of age). Based on the survey conducted, there were still many problems in families who did not want their children to be immunized in Maharani Village, Rumbai District. Therefore, it needs to be resolved by holding outreach on Universal Child Immunization (UCI).
\end{abstract}

Keywords: Socialization, Immunization, UCI

\begin{abstract}
ABSTRAK
Program imunisasi merupakan salah satu upaya untuk memberikan perlindungan kepada penduduk terhadap penyakit tertentu. Program imunisasi diberikan kepada populasi yang dianggap rentan terjangkit penyakit menular, yaitu bayi, balita, anak-anak, wanita usia subur, dan ibu hamil. Melalui program ini, Indonesia dinyatakan bebas dari penyakit cacar oleh WHO sejak tahun 1974. Di Indonesia, program imunisasi mewajibkan setiap bayi (usia 0-11 bulan) mendapatkan imunisasi dasar lengkap yang terdiri dari 1 dosis Hepatitis B, 1 dosis BCG, 3 dosis DPT-HB-Hib, 4 dosis polio, dan 1 dosis campak. Salah satu indikator keberhasilan program imunisasi adalah tercapainya Universal Child Immunization (UCI) adalah suatu keadaan tercapainya imunisasi dasar secara lengkap pada semua bayi (anak dibawah umur satu tahun). Berdasarkan survey yang dilakukan masih banyak ditemukan masalah dalam hal dikeluarga yang tidak mau anaknya di imunisasi di Kelurahan MaharaniKecamatan Rumbai.Maka dari itu, perlu diatasi dengan diadakannya sosialisasi tentang Universal Child Immunization (UCI).
\end{abstract}

Kata Kunci: Sosialisasi, Imunisasi, UCI 


\section{PENDAHULUAN}

Imunisasi adalah suatu upaya untuk menimbulkan/meningkatkan kekebalan seseorang secara aktif terhadap suatu penyakit tertentu, sehingga bila suatu saat terpapar dengan penyakit tersebut tidak akan sakit atau hanyamengalami sakit ringan. Beberapa penyakit menular yang termasuk ke dalamPenyakit yang Dapat Dicegah dengan Imunisasi (PD3I) antara lain TBC, Difteri,Tetanus, Hepatitis B, Pertusis, Campak, Polio, radang selaput otak, dan radangparu-paru. Anak yang telah diberi imunisasi akan terlindungi dari berbagaipenyakit berbahaya tersebut, yang dapat menimbulkan kecacatan atau kematian. Imunisasi merupakan salah satu intervensi kesehatan yang terbukti paling costeffective(murah), karena dapat mencegah dan mengurangi kejadian kesakitan,kecacatan, dan kematian akibat PD3I yang diperkirakan 2 hingga 3 juta kematiantiap tahunnya(Kemenkes, 2016).

Program imunisasi merupakan salah satu upaya untuk memberikan perlindungan kepada penduduk terhadap penyakit tertentu. Program imunisasi diberikan kepada populasi yang dianggap rentan terjangkit penyakit menular, yaitu bayi, balita, anak-anak, wanita usia subur, dan ibu hamil. Melalui program ini, Indonesia dinyatakan bebas dari penyakit cacar oleh WHO sejak tahun 1974. Di Indonesia, program imunisasi mewajibkan setiap bayi (usia 0-11 bulan) mendapatkan imunisasi dasar lengkap yang terdiri dari 1 dosis Hepatitis B, 1 dosis BCG, 3 dosis DPT-HB-Hib, 4 dosis polio, dan 1 dosis campak. (Kemenkes, 2016).

Profil kesehatan Indonesia (2016) menyebutkan dari Imunisasi dasar lengkap yang diwajibkan, campak menjadi salah satu jenis imunisasi yang mendapat perhatian lebih, hal ini sesuai dengan komitmen Indonesia pada global untuk turut serta dalam eliminasi campak pada tahun 2020 dengan mencapai cakupan campak minimal 95\% di semua wilayah secara merata. Hal ini terkait dengan realita bahwa campak menjadi salah satu penyebab utama kematian pada balita.

Salah satu indikator keberhasilan program imunisasi adalah tercapainya Universal Child Immunization (UCI) adalah suatu keadaan tercapainya imunisasi dasar secara lengkap pada semua bayi (anak dibawah umur satu tahun).

Penyebab utama rendahnya pencapaian UCI adalah rendahnya akses pelayanan dan tingginya angka drop out. Hal ini antara lain terjadi karena tempat pelayanan imunisasi jauh dan sulit dijangkau, jadwal pelayanan imunisasi tidak teratur dan tidak sesuai dengan 
kegiatan masyarakat, kurangnya tenaga, tidak tersedianya buku imunisasi (buku KIA), rendahnya kesadaran dan pengetahuan masyarakat tentang manfaat, waktu pemberian imunisasi serta gejala ikutan imunisasi. Selain itu faktor budaya dan pendidikan serta kondisi sosial ekonomi juga ikut mempengaruhi rendahnya pencapaian UCI desa/kelurahan.(Kepmenkes No 482, 2010).

\section{METODE KEGIATAN}

Metode pengabdian masyarakat ini dilaksanakan dalam bentuk penyuluhan dengan mengangkat tema "Sosialisasi Pentingnya Imunisasi Untuk Mencapai Universal Child Immuzation (UCI)" dengan memberikan ceramah langsung dan leaflet berisi materi dan gambar yang menarik serta Tanya jawab seputar Imunisasi, pentingnya imunisasi, jadwal imunisasi, tujuan imunisasi pada anak yang dapat membantu menurunkan angka kesakitan, kecacatan dan kematian akibat penyakit yang dapat dicagah dengan imunisasi. Dan Melakukan pendataan kepada ibu tentang kelengkapan imunisasi anaknya sehingga dapat dilakukan deteksi dini tentang imunisasi sehingga ibu mau mengimunisasikan anaknya.

\section{HASIL DAN PEMBAHASAN}

\section{Hasil Pelaksanaan}

Kegiatan yang dilakukan dalam pengabdian kepada masyarakat ini dilaksanakan dalam beberapa tahapan yang diawali dengan pemberian penyuluhan terlebih dahulu tentang Imunisasi, pentingnya imunisasi, jadwal imunisasi, tujuan imunisasi pada anak yang dapat membantu menurunkan angka kesakitan , kecacatan dan kematian akibat penyakit yang dapat dicagah dengan imunisas

Kegiatan sosialisasi Universal Child Immunization (UCI) ini telah dilaksanakan pada bulan November 2019 pada masyarakat Keluraan MaharaniKecamatan Rumbai. Berdasarkan pengamatan selama kegiatan berlangsung, kegiatan pegabdian pada masyarakat ini memberikan hasil sebagai berikut :

Meningkatnya pengetahuan dan pemahaman masyarakat tentang pentingnya imunisasi, manfaat imunisasi, tujuan imunisasi dan jadwal imunisasi anak yang tergantung pada kurangnya informasi atau pengetahuan serta jarak rumah dengan fasilitas kesehatan yang terbilang cukup jauh. 
Hal ini dilihat dari kemampuan masyarakat yang mampu menjawab pertanyaan-pertanyaan yang diberikan pemateri.
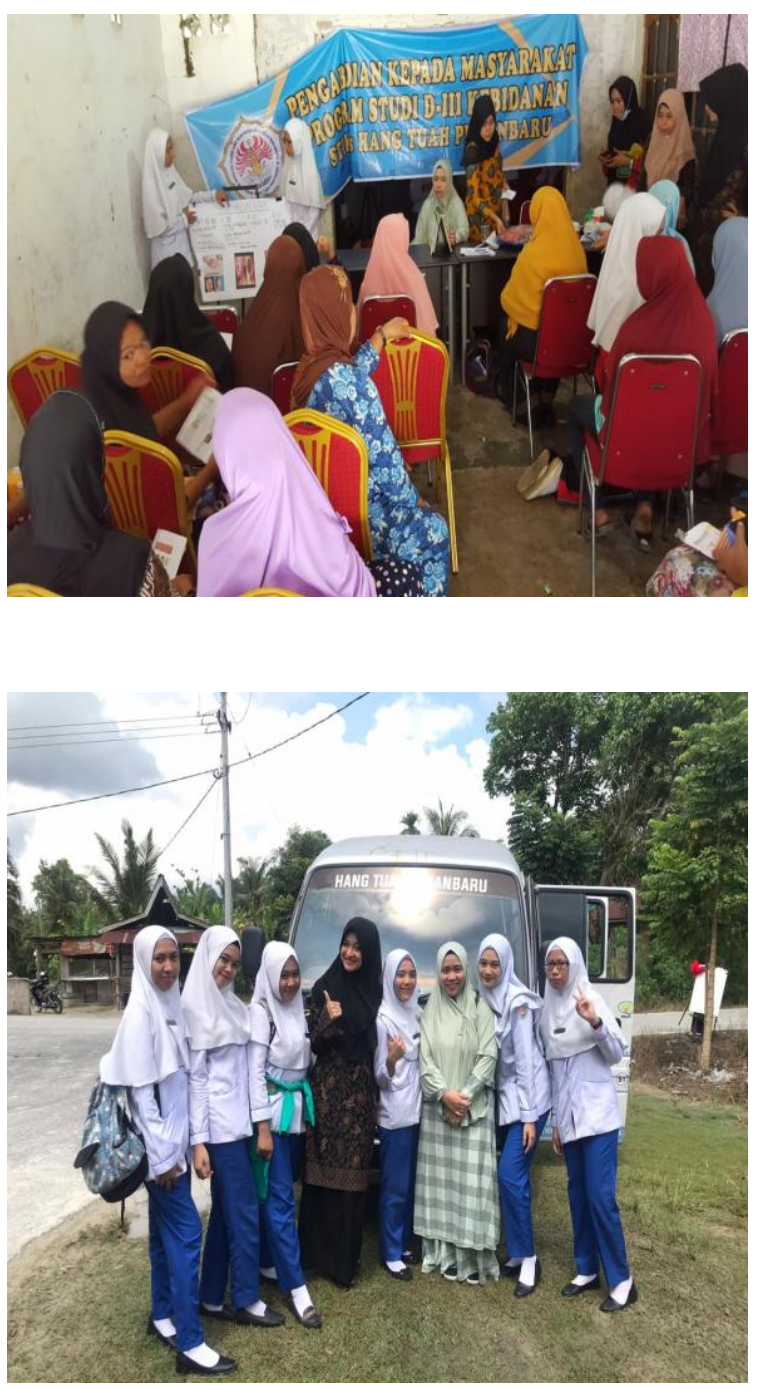

\section{Pembahasan}

Kegiatan penyuluhan tentang sosialisasi Universal Child Immunization (UCI) di Kelurahan Maharani Kecamatan Rumbai berjalan dengan sangat baik. Hal ini terlihat dari antusias nya para ibu yang mempunyai bayi yang hadir pada saat kegiatan berlangsung banyak para ibu yang bertanya menunjukkan rasa ingin tahu mereka terhadap materi yang disampaikan. Selama ini, pengetahuan ibu yang memiliki bayi tentang imunisasi adalah masalah yang biasa baginya, tetapi setelah mendengarkan penyuluhan ini para ibu yang memiliki bayi mengerti tentang pentingnya imunisasi, jadwal imunisasi, tujuan imunisasi pada anak yang dapat membantu menurunkan angka kesakitan , kecacatan dan kematian akibat penyakit yang dapat dicagah dengan imunisasi.

Program imunisasi merupakan salah satu upaya untuk memberikan perlindungan kepada penduduk terhadap penyakit tertentu. Program imunisasi diberikan kepada populasi yang dianggap rentan terjangkit penyakit menular, yaitu bayi, balita, anak-anak, wanita usia subur, dan ibu hamil. Melalui program ini, Indonesia dinyatakan bebas dari penyakit cacar oleh WHO sejak tahun 1974. Di Indonesia, program imunisasi mewajibkan setiap bayi (usia 0-11 bulan) mendapatkan imunisasi dasar lengkap yang terdiri dari 1 dosis Hepatitis B, 1 dosis BCG, 3 dosis DPT-HB-Hib, 4 dosis polio, dan 1 dosis campak. (Kemenkes, 2016).

\section{KESIMPULAN}

Disimpulkan bahwa angka pencapaian program imunisasi berdasarkan kriteria 
UCI 4 di Kelurahan Maharani Kecamatan Rumbaimasih rendah.Disebabkan dari segi masyarakat, masih terdapat persepsi negatif mengenai imunisasi, kurangnya informasi dari mitra pelayanan program imunisasi.

Meningkatnya pengetahuan dan pemahaman masyarakat tentang pentingnya imunisasi, manfaat imunisasi, tujuan imunisasi dan jadwal imunisasi anak yang tergantung pada kurangnya informasi atau pengetahuan serta jarak rumah dengan fasilitas kesehatan yang terbilang cukup jauh.Hal ini dilihat dari kemampuan masyarakat yang mampu menjawab pertanyaan-pertanyaan yang diberikan pemateri.

\section{DAFTAR PUSTAKA}

1. Departemen Kesehatan RI. Sistem Kesehatan Nasional. Cetakan ke-4. Jakarta. 1995

2. http://www.unicef.org/indonesia/id/me dia.html diunduh tanggal 24 November 2019

3. http://repository.dinamika.ac.id/id/epri nt/1856/4/BAB_II.pdf diunduh tanggal 24 November 2019

4. http://repositori.usu.ac.id/bitstream/ha ndle/123456789/8093/141000122.pdf ?sequence $=1 \&$ is Allowed $=\mathrm{y} \quad$ diunduh tanggal 24 November 2019 